Cinémas

Revue d'études cinématographiques

Journal of Film Studies

\title{
Du filmique au littéraire : les textes des catalogues de la cinématographie-attraction
}

\section{André Gaudreault et Philippe Marion}

Volume 15, numéro 2-3, printemps 2005

Cinélekta 5

URI : https://id.erudit.org/iderudit/012323ar

Aller au sommaire du numéro

Éditeur(s)

Cinémas

ISSN

1181-6945 (imprimé)

1705-6500 (numérique)

Découvrir la revue

Citer cet article

Gaudreault, A. \& Marion, P. (2005). Du filmique au littéraire : les textes des catalogues de la cinématographie-attraction. Cinémas, 15(2-3), 121-145.
Résumé de l'article

Les descriptifs que les premiers « fabricants » de vues animées publient dans leurs catalogues sont des textes scripturaux produits sur la base d'un texte iconique préexistant. Ce sont des textes fonctionnels davantage que fictionnels, qui visent à traduire au mieux, au moyen du langage verbal, le contenu et, à la fois, l'esprit d'un film. Une fois que l'effet novelty du cinématographe se serait estompé, l'écriture plus proprement « littéraire » allait bientôt reprendre ses droits, d'autant plus que, dans sa phase d'institutionnalisation, le cinéma allait devenir narratif. Le " catalogueur " allait ainsi être amené à se transformer en " publirédacteur ", pour produire des textes "novellisés " qui seraient plus respectueux du média scriptural. 


\title{
Du filmique au littéraire: les textes des catalogues de la cinématographie-attraction ${ }^{1}$
}

\section{André Gaudreault et Philippe Marion}

\begin{abstract}
RÉSUMÉ
Les descriptifs que les premiers "fabricants" de vues animées publient dans leurs catalogues sont des textes scripturaux produits sur la base d'un texte iconique préexistant. Ce sont des textes fonctionnels davantage que fictionnels, qui visent à traduire au mieux, au moyen du langage verbal, le contenu et, à la fois, l'esprit d'un film. Une fois que l'effet novelty du cinématographe se serait estompé, l'écriture plus proprement "littéraire" allait bientôt reprendre ses droits, d'autant plus que, dans sa phase d'institutionnalisation, le cinéma allait devenir narratif. Le "catalogueur» allait ainsi être amené à se transformer en "publirédacteur", pour produire des textes "novellisés» qui seraient plus respectueux du média scriptural.
\end{abstract}

\section{ABSTRACT}

The descriptive texts that the earliest "manufacturers" of animated pictures published in their catalogues are scriptural texts based on a pre-existing iconic text. These texts are more functional than fictional, for they strive to best translate, through the means of verbal language, not just the content but also the spirit of a film. As soon as the novelty effect of the cinematograph had worn off, writing more distinctly literary in nature would promptly assert its rightful place, especially since, in its institutional phase, cinema would become narrative. The "cataloguer" would hence be lead to transform into a "publiwriter" in order to produce novelized text that would be more representative of scriptural media. 
Dans une communication présentée à ce qui fut peut-être le premier colloque sur la novellisation (Université de Louvain, novembre $2003^{2}$ ), les deux auteurs du présent article proposaient un cadre réflexif portant sur cette pratique, assez précoce, de «transmédialisation» image/texte que suppose l'écriture des résumés des catalogues publiés par les «fabricants de vues animées". Au même titre que la novellisation, la rédaction de ces descriptifs, qui devaient permettre aux «exhibiteurs" de sélectionner les produits les plus susceptibles d'intéresser leur clientèle, impliquait la production de textes scripturaux rédigés sur la base de textes iconiques préexistants. Cependant, au contraire des textes normalement produits dans le cadre d'un processus de novellisation, au sens où on l'entend généralement, ces descriptifs sont d'abord et avant tout des textes fonctionnels. La préoccupation du catalogueur de l'époque de la "cinématographie-attraction ${ }^{3}$ " (que l'on situe entre 1895 et 1908) est de donner à l'acheteur potentiel une idée de la vue mise en vente. Il ne s'agit pas, pour lui, de produire un texte qui aurait une valeur en soi. Le descriptif doit en effet serrer au plus près, par le truchement du langage verbal, le contenu et l'esprit de la vue.

On constate que les descriptifs de la toute première période du corpus étudié font preuve d'un certain mimétisme intermédiatique, leurs rédacteurs allant jusqu'à tenter la transposition, dans le scriptural, de certains des traits propres au nouveau mode, iconique, d'expression. L'exercice de "transsémiotisation» auquel se sont adonnés les premiers catalogueurs les amène, le plus souvent, à chercher à établir une sorte de traduction en mots de la fibre «médiale» du texte filmique, ce qui les pousse à imaginer en quelque sorte des équivalents scripturaux de données purement iconiques. L'écrit et le filmique étant deux véhicules sémiotiques franchement hétérogènes, on pourrait arguer que les catalogueurs de la cinématographie-attraction, en ignorant la barrière des espèces médiatiques, ont été victimes d'une certaine forme de naïveté.

Une pareille condition d'asservissement du média scriptural au média iconique n'allait pas durer indéfiniment, comme nous allons le constater. Nous verrons en effet ici comment le catalogueur de la cinématographie-attraction est appelé, une fois le 
cinéma parvenu au seuil de l'institution, à se transformer en un genre de "publirédacteur " et à produire un texte "novellisé » d'une tout autre nature que celui qui prévalait au tournant du siècle: un texte qui ne s'inscrit plus dans la tradition du mimétisme descriptif des premiers catalogueurs. C'est un peu comme si on finissait par reconnaître que le média filmique possédait désormais sa spécificité, son langage, sa légitimité, sa visibilité médiatique, et qu'il était devenu aussi vain qu'inutile d'essayer de le traduire dans un autre média. L'exercice de rédaction ne consisterait plus, dès lors, en une simple traduction; il doit dorénavant se présenter comme une transposition, voire une adaptation du contenu du film dans le média scriptural d'arrivée, en respectant celui-ci et ses principes.

Illustrons d'abord les deux extrémités de ce spectre par deux exemples représentatifs des tendances notées. Le mimétisme descriptif représentatif de la toute première période paraît évident dans cet exemple tiré d'un catalogue du "cinématographiste" anglais James Williamson (il s'agit de la description d'une vue datant de 1899, provenant de la série intitulée "One-Minute Comedies $\left.{ }^{4} »\right)$ :

Two Naughty Boys Teasing the Cobbler.

Cobbler at work; two boys bring shoes to mend; boys stand outside with pea-shooter; cobbler jumps. No, I didn't do anything!

On remarque l'aspect brut, saccadé, quasi immédiat du texte du catalogue Williamson, tentant, semble-t-il, de cerner l'esprit cinéma, sans chercher à produire d'effet littéraire autonome. Le descriptif semble, en effet, inspiré du cinétisme propre au nouveau média. Mimétisme stylistique et informationnel: le texte ne dit rien de plus que ce qu'il y a dans la vue.

Voyons maintenant un exemple qui se situe à l'autre extrême. Il s'agit du descriptif de His Last Burglary, réalisé par Griffith pour la Biograph en 1910, dont voici un extrait:

The Scottish poet, Robert Pollock, called children "Living jewels dropped unstained from heaven," and this esteem is backed by Scriptural evidence, for the Saviour came to us as a child. He ever specialized the 
child. He taught that a little child should lead them. And so it is; the tiny hand of the baby has ever been the propelling force of the universe. Never was this more vividly portrayed than in this Biograph subject. William Standish, a young inventor, like many of his ilk, has spent time, money and energy in perfecting a machine which the engineers to whom he had submitted it are slow in deciding upon, during which time he and his little family of a wife and infant child are in poverty's clutches (dans Bowser 1973, p. 170).

L'emprise littéraire, à tout le moins d'une certaine conception stéréotypée de la littérature classique, apparaît ici d'emblée. Le texte s'ouvre sur une mise en exergue et un incipit moralisateur, tous deux placés sous le signe de la référence littéraire, par la convocation de l'imagerie verbale (non pas iconique) emphatique d'un poète écossais. Le portrait du personnage de l'inventeur s'inspire par ailleurs largement des clichés littéraires ambiants, tout en donnant une série d'informations que le film, pour sa part, ne livre nullement. Ce texte ne relève pas du mimétisme stylistique et informationnel observé dans le premier exemple. En tout cas, si mimétisme il y a, ce serait plutôt celui qui implique la soumission aux canons et aux topoïlittéraires.

Outre le fait que ce second exemple se rapproche de la conception courante de la novellisation, on note aussi, entre l'exemple Williamson et l'exemple Griffith, une distance notable, qui indique l'appartenance respective des deux cas à des registres franchement différents. Chacun de ces registres semble correspondre à l'un des "modes de pratique filmique" jadis identifiés par l'un d'entre nous (avec Tom Gunning), et qui se seraient succédé à l'horizon de l'histoire: d'une part, le "système des attractions monstratives ", qui aurait dominé jusqu'aux environs de 1908, et, d'autre part, le "système d'intégration narrative" qui lui aurait succédé 5 . En effet, il semble bien que, dans le cas de Williamson, l'on se situe nettement du côté de l'attraction, tandis que celui de Griffith nous fait basculer du côté de la narration. 


\section{Traduction, mimétisme, infranovellisation :}

\section{les catalogueurs de la cinématographie-attraction}

À une époque où, encore loin de sa reconnaissance institutionnelle, le cinéma — ou plutôt le cinématographe — évolue sous l'aura de la novelty de son dispositif, la tendance au mimétisme que l'on a remarquée chez les premiers catalogueurs est une tendance dominante. Sur le plan prosodique, les textes réunis dans leurs catalogues évoquent le cinétisme et la rythmicité associés à la fascination exercée par la nouvelle machine, par le nouveau procédé. En adhérant à l'emprise du média iconique, le catalogueur de la cinématographie-attraction néglige en quelque sorte deux spécificités: celle, médiatique, du scriptural, et celle, générique, du modèle dominant de la rédaction «littéraire».

Voyons la chose d'un peu plus près, à partir du descriptif d'une autre vue tiré du catalogue de Williamson (vue qui fait partie de la même série que celle mentionnée ci-dessus $\left.{ }^{6}\right)$ :
Two Naughty Boys Upsetting the "Spoons."
Two boys playing with bat and ball in garden; gentle- man arrives; where is aunty? Boy points through opening; aunty arrives; animated conversation; boy takes away gent's cigarette, dropping racquet behind him; etc.

On note une accumulation d'actions énoncées brièvement, à la queue leu leu, de façon lacunaire, sur un mode où la fébrilité ne le cède en rien à la rapidité, comme si l'on avait voulu traduire, par la facture du texte, si ce n'est sa "fracture", le rythme saccadé de l'action, comme si l'on avait cherché à traduire, par ces saccades, le génie cinétique du cinématographe lui-même: des phrases incomplètes et segmentées, des microséquences verbales s'enchaînant les unes à la suite des autres, sans véritable articulation, des points-virgules servant de ponctuation, etc. En décrivant de la sorte un film, le catalogueur de la cinématographie-attraction en vient, finalement, à décrire le film, le film dans son "essence", si l'on peut dire, dans sa fascinante nouveauté médiatique. D’où l'écriture syncopée, le style heurté, la prosodie saccadée et télégraphique, autant de caractéristiques qui ont fait les beaux jours du cinématographe, selon plusieurs commentateurs de l'époque. Ainsi le clame, par exemple, 
G.-Michel Coissac qui, dans un texte daté de 1911, conseille au conférencier de ne pas même s'essayer à concurrencer par son verbe l'aspect frénétique des images en mouvement:

Il serait vain de causer pendant que se projettent les vues animées: toute l'attention est accaparée par elles. D'autre part, il semble que ces vues mâchent les syllabes des mots que l'on désirerait leur appliquer. Chaque tremblement devient une virgule, un trait de sursaut que, par les yeux, reçoit le sens de l'ouïe (Coissac 1911).

Des textes de catalogue comme ceux de Williamson ne visent donc pas l'affranchissement esthétique, ne serait-ce que parce qu'ils empruntent souvent des raccourcis télégraphiques qui, par l'éclat proprement attractionnel de leur phrasé, ne peuvent faire autrement que d' "obscurcir la forme». Ces textes renoncent donc à leur propre transparence textuelle. En effet, c'est d'abord et avant tout l'opacité médiatique, du moins une certaine opacité médiatique, qui les singularise. Remarquons cependant que, par un curieux renversement, ces caractéristiques formelles dépourvues d'intentionnalité littéraire en viennent parfois, par leur opacité même, à ressembler à des expressions poétiques plus élitistes et, partant, plus... littéraires. N'y a-t-il pas, en effet, dans le caractère haché et compact de ces textes, un soupçon de futurisme, voire de dadaïsme (avant la lettre, bien entendu) ?

Par «opacité», on entendra plutôt ici le fait que les descriptifs ne sont pas autonomes, qu'ils sont complémentaires à d'autres textes (des textes iconiques), auxquels ils font référence - dont ils sont la référence, en fait. En ce sens, ces textes ne seraient que des faire-valoir... Cette opacité est omniprésente, non seulement en raison de la brièveté télégraphique des textes, mais aussi en raison des nombreuses notations réflexives dont ils sont émaillés, et qui sont de deux ordres. Il y a d'abord celles, indirectes, qui s'imposent par les constantes références au texte - filmique absent, puis celles, directes, ayant trait au nouveau média.

Occupons-nous d'abord des références au texte absent. Un processus le moindrement orthodoxe de novellisation viserait, normalement, une totale transparence médiatique: un pareil processus consisterait en effet en la réalisation pour un autre 
média (un média $\mathrm{B}$, disons) d'un texte qui aurait, dans ce nouveau média, une autonomie complète. Il s'agirait donc d'un texte qui occulterait toute référence explicite au média originel (le média $\mathrm{A}$ ), et toute référence explicite à la facture proprement médiatique du texte d'origine. Au contraire, tout se passe, avec les premiers descriptifs, comme si l'on essayait d'utiliser les signes du média B (le scriptural) pour rendre compte, dans ce média, des effets produits sur le public par le média A (le filmique), au moyen des signes propres à ce dernier.

Ce que vise donc la description du catalogue, c'est de remplacer le texte - iconique - du média A par un tenant-lieu, produit par l'intermédiaire d'un autre média. La chose s'explique bien dès lors que l'on tient compte de la fonction de ces descriptifs: ils sont là, devant nous, non pas pour que nous les appréciions en raison de leurs qualités propres, mais pour que nous devinions, à travers eux, le texte absent, celui de la vue qu'ils « re-présentent».

De la même façon que certains médias contemporains se laissent oublier au profit de ce qu'ils transmettent, les descriptifs des catalogues de la cinématographie-attraction sont transparents dans le sens où ils tendent à s'effacer au profit de leur fonction, qui est de laisser transparaître la vue dont ils tiennent lieu. Ces textes sont en effet produits en vue de permettre à l'acheteur potentiel (l'exhibiteur) de se passer de la vue pour faire son choix, et de se la passer, cette vue, dans la tête, de s'en offrir une vision, pour ensuite procéder à une sélection de la marchandise qu'il entend proposer à ses clients-spectateurs.

Voilà pourquoi le texte de ces descriptifs ne relève pas de quelque velléité d'adaptation que ce soit. Il ne s'agit pas ici de remplacer un texte poétique iconique par un texte poétique scriptural, mais de donner de celui-là une description relativement fidèle. La fidélité revêt d'ailleurs ici une signification particulière: il s'agit d'une fidélité fonctionnelle et pragmatique, indispensable à la viabilité du produit filmique.

Occupons-nous maintenant des références au média nouveau que recèlent les premiers descriptifs. En voici quelques exemples (nous indiquons entre crochets le catalogue de référence) :

- Projects highly magnified. An interesting subject [Maguire et Baucus, automne 1897]. 
- A very effective film. [...] A beautifully clear film, and very popular [Williamson, septembre 1902].

- Cette scène $[. .$.$] produit des effets tout à fait inat-$ tendus [Pathé, 1902].

- Cette vue est un des trucs les plus extraordinaires [...] [Méliès, 1901].

L'effet comique [d]es scènes renversées étant toujours irrésistible [...] [Pathé, 1901].

On s'émerveille, on s'exclame, on brandit le caractère exceptionnel de la vue en tant que produit et du média par le truchement duquel il parvient au spectateur. Ce genre d'évaluation sur la performance du film en termes de novelty distingue nettement, à n'en pas douter, les textes de notre corpus de ceux qui seraient réalisés dans le cadre d'un processus orthodoxe de novellisation.

\section{La dramatisation comme signal de transition}

Comme on l'a dit plus haut, une fois le cinéma parvenu au seuil de l'institution, le catalogueur est finalement amené à produire un texte "novellisé », en phase avec les "compétences" du média d'arrivée (le scriptural). En plein cœur de la poussée institutionnalisante que le cinéma a connue, au tournant des années 1910, la tendance dominante consiste en effet à produire, dorénavant, des textes scripturaux disjoints des textes filmiques, des textes qui délaissent ainsi le mimétisme "descriptionniste» des premiers catalogueurs. La préoccupation dominante s'est transformée: il s'agit non plus de rendre l'idée du film par la traduction de son mouvement et de ses variations, par des mots et leur agencement syntaxique, mais plutôt de transposer cette idée dans le média scriptural d'arrivée, en respectant ce média et ses principes.

En d'autres termes, dès lors que l'effet novelty du cinéma s'estompe, il n'est plus guère utile d'essayer de rendre compte de cet effet avec les moyens scripturaux du bord. Lécriture peut ainsi reprendre ses droits "littéraires", et ce d'autant plus qu'il s'agit, dans la phase de l'institutionnalisation du média, de présenter par 
le film des récits, l'un des domaines privilégiés de la littérature, comme chacun sait. Dès lors, les velléités "média-mimétiques" sont abandonnées au profit d'un recentrage sur le contenu narratif des films. Tout se passe comme si les rédacteurs de descriptifs renonçaient à l'idée de pouvoir suivre un film... à la lettre.

Dorénavant, les descriptifs ne se réferent plus que rarement au film lui-même, dans la mesure où ils s'éloignent des singularités iconico-médiatiques de celui-ci, en se contentant de retracer sa trame narrative. Du reste, cette tendance se manifeste bien avant sa cristallisation au début des années 1910. On en trouve la trace à travers, notamment, la recherche d'une dramatisation scripturale (pas nécessairement présente dans le texte filmique lui-même), qui distinguait ces textes des descriptifs laconiques et télégraphiques des débuts.

Ainsi en va-t-il, pour prendre un exemple connu, du texte présentant Life of an American Fireman (Edison, 1903) :

\begin{abstract}
The frantic mother having returned to consciousness, and clad only in her night clothes, is kneeling on the ground imploring the firemen to return for her child. Volunteers are called for and the same fireman who rescued the mother quickly steps out and offers to return for the babe. He is given permission to once more enter the doomed building and without hesitation rushes up the ladder, enters the window and after a breathless wait, in which it appears he must have been overcome by smoke, he appears with the child on his arms and returns safely to the ground ${ }^{7}$.
\end{abstract}

Ici, le catalogue en met plein la vue et va jusqu'à proposer une lecture incompatible avec la lecture de la version filmique du soidisant même récit. En effet, à ce moment-là du film, il n'y a aucun suspense de ce genre, aucune attente angoissante. Le spectateur n'a pas le moins du monde peur que le pompier ne meure asphyxié et qu'il soit incapable de rendre l'enfant à sa mère, pour la simple et bonne raison que le spectateur vient tout juste de voir, quelques secondes plus tôt (mais depuis l'intérieur de la maison en flammes), que l'action de sauvetage a été une réussite totale et que le pompier a bel et bien pu sortir l'enfant de la chambre en feu (figure 1, p. 130-131). 

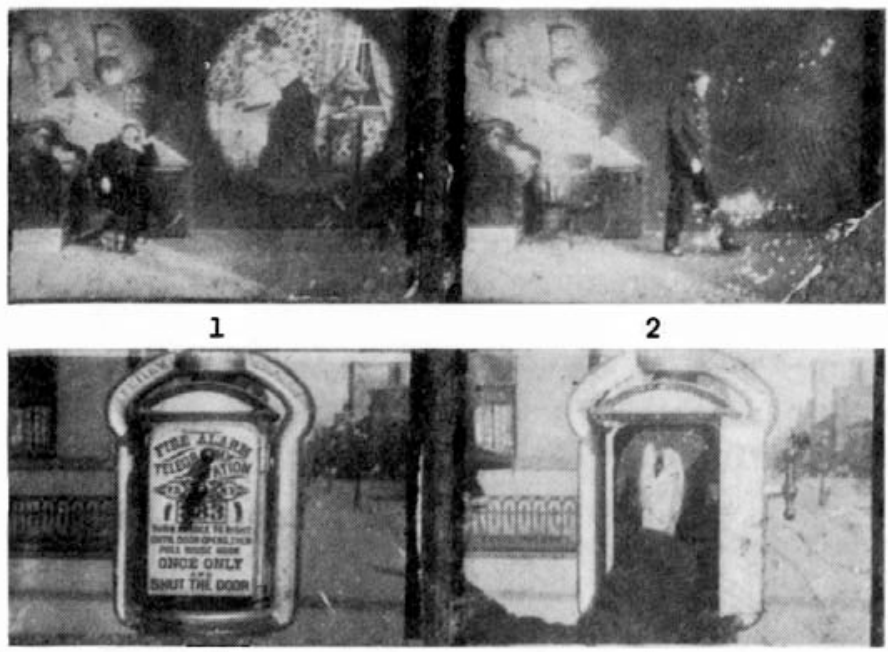

3

4
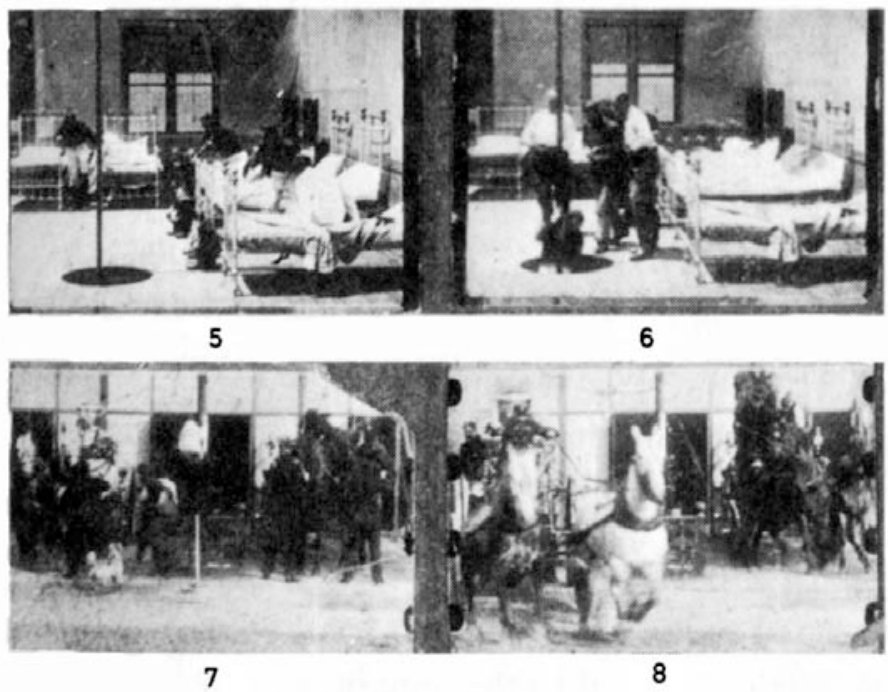

130 CiNeMAS, vol. 15, n"2-3 

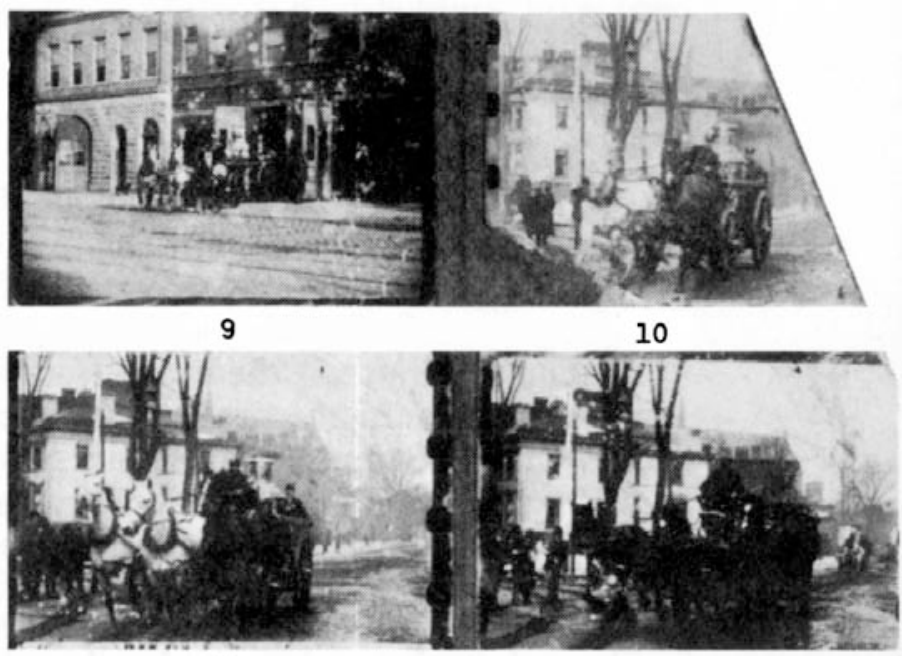

11

12

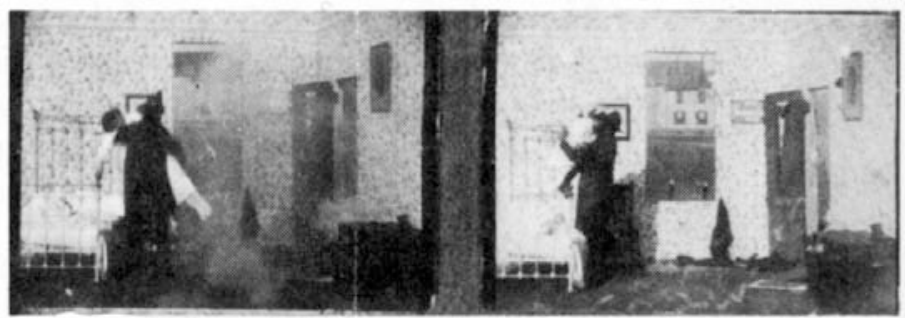

13

14

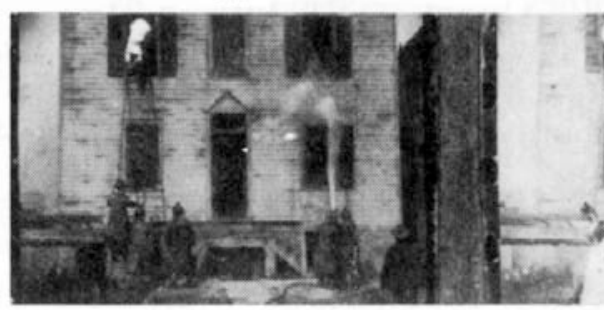

15

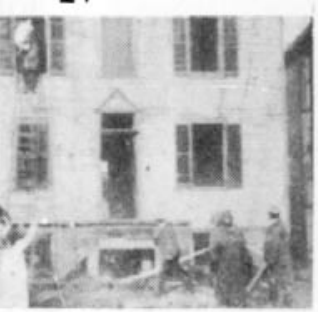

16

Figure 1. Life of an American Fireman (Edison, 1903). La "Jamison continuity» dans sa forme originale (nous lui avons superposé des bandes blanches pour permettre la numérotation des photogrammes selon leur ordre d'apparition dans le film). On remarquera le photogramme $n^{\circ} 14$, qui présente le sauvetage de l'enfant, vu depuis l'intérieur de la maison, puis le photogramme $\mathrm{n}^{\circ} 15$, tiré du plan suivant, à la fin duquel la mère demande avec angoisse au pompier d'aller sauver son enfant, sauvetage auquel le spectateur a déjà pu assister une première fois...

Du filmique au littéraire : les textes des catalogues de la cinématographie-attraction 
Dès lors qu'il commence à se placer dans la zone d'influence du modèle littéraire, le catalogueur n'hésite pas à souligner, voire à amplifier les aspects dramatiques de telle ou telle situation filmique. Le texte du catalogue prend une certaine distance avec le texte d'origine (le texte filmique), et il se donne un programme narratif et discursif qui lui est propre. En fait, l'instance scripturale anticipe sur cette figure essentielle du cinéma institutionnel qu'est le suspense, et provoque l'attente angoissante qui en est le corollaire. Le scripteur des catalogues se permet donc, à point nommé, de donner une "valeur ajoutée " au texte filmique: il le dramatise.

Le descriptif de Life of an American Fireman se situerait ainsi dans une zone de transition. Comme le montre cette exclamation admirative à propos de la performance du média: «[...] the most thrilling and in all the most wonderful of the seven scenes of the series", on trouve encore, dans le texte du catalogue, quelques traces de la prise en compte de l'effet novelty. Une prise en compte qui côtoie les signes d'une novellisation plus orthodoxe, plus proche d'un principe d'adaptation hanté par l'effet littéraire.

\section{Transposition et novellisation :}

l'autonomie du «publirédacteur» du cinéma narratif

L'autonomisation littéraire du texte de catalogue se manifeste donc clairement dans le bulletin de la Biograph datant de 1910 et présentant le film His Last Burglary. Comme on l'a vu, ce texte se place d'emblée sous la tutelle d'une citation littéraire qui offre, à l'instar d'une fable, une morale ou une maxime qui oriente les horizons d'attente du lecteur. Avec force pathos et images fleuries, on y célèbre la force sacrée et universelle de l'enfance: " [...] the tiny hand of a baby has ever been the propelling force of the universe». On ne trouve pourtant aucune trace de ce conditionnement moralisant dans le film, qui illustre d'entrée de jeu l'un des éléments déterminant le récit en question, soit la pauvreté du jeune inventeur. Cette autonomie à caractère littéraire du bulletin de la Biograph va jusqu’à mener le rédacteur à modifier, dans son texte scriptural, l'ordre du découpage et la structure même des actions proposées par le film. 
Le texte filmique de His Last Burglary fait en effet s'articuler deux lignes d'action principales, polarisées par deux ensembles actantiels distincts qui sont mis en parallèle: celui de l'inventeur et de son épouse (A) et celui du voleur et de sa femme (B) (il existe aussi, de façon subsidiaire, un troisième ensemble, celui du pasteur et de sa famille [C]). Dans le récit filmique, les lignes d'action sont appelées à s'entrecroiser selon la structure suivante (remarquez l'occurrence unique du troisième ensemble actantiel) : $\mathrm{A} / \mathrm{B} / \mathrm{A} / \mathrm{C} / \mathrm{A} / \mathrm{B} / \mathrm{A} / \mathrm{B} / \mathrm{A} / \mathrm{B} / \mathrm{A} / \mathrm{B} / \mathrm{A} / \mathrm{B}$ (figure 2, p. 134-135).

Pour sa part, le texte scriptural propose une structure fondée sur une alternance beaucoup plus simple, sur le plan narratologique. Après l'incipit moralisateur que nous avons cité, viennent quatre segments différenciés, où les séries alternent une seule fois entre elles, selon le schéma suivant: $\mathrm{A} / \mathrm{B} / \mathrm{A} / \mathrm{B}$, une structure singulièrement moins complexe que celle du film (voir le texte complet, figure 3, page 137).

Voici comment est présentée la première occurrence de l'ensemble actantiel A (l'inventeur et son épouse):

William Standish, a young inventor, like many of his ilk, has spent time, money and energy in perfecting a machine which the engineers to whom he had submitted it are slow in deciding upon, during which time he and his little family of a wife and infant child are in poverty's clutches. Starvation stares them in the face. The baby gives them the most concern, and after a desperate mental struggle, they decide to leave it clandestinely in the minister's care. To this end they go to the minister's house at night, and being the dead of winter haven't the heart to leave it on the stoop, so Standish climbs through the window and leaves it in the sitting-room on an arm-chair.

Celle-ci est suivie d'une première occurrence de l'ensemble actantiel B (le voleur et sa femme):

In the neighbourhood there lives a professional burglar, whose wife we see bending over an empty cradle mourning the loss of her child. The burglar, despite his calling, is moved by his wife's sorrow, and leaves the house dejectedly on an expedition. The open window in the minister's home looks rather inviting, Standish

Du filmique au littéraire: les textes des catalogues de la cinématographie-attraction 

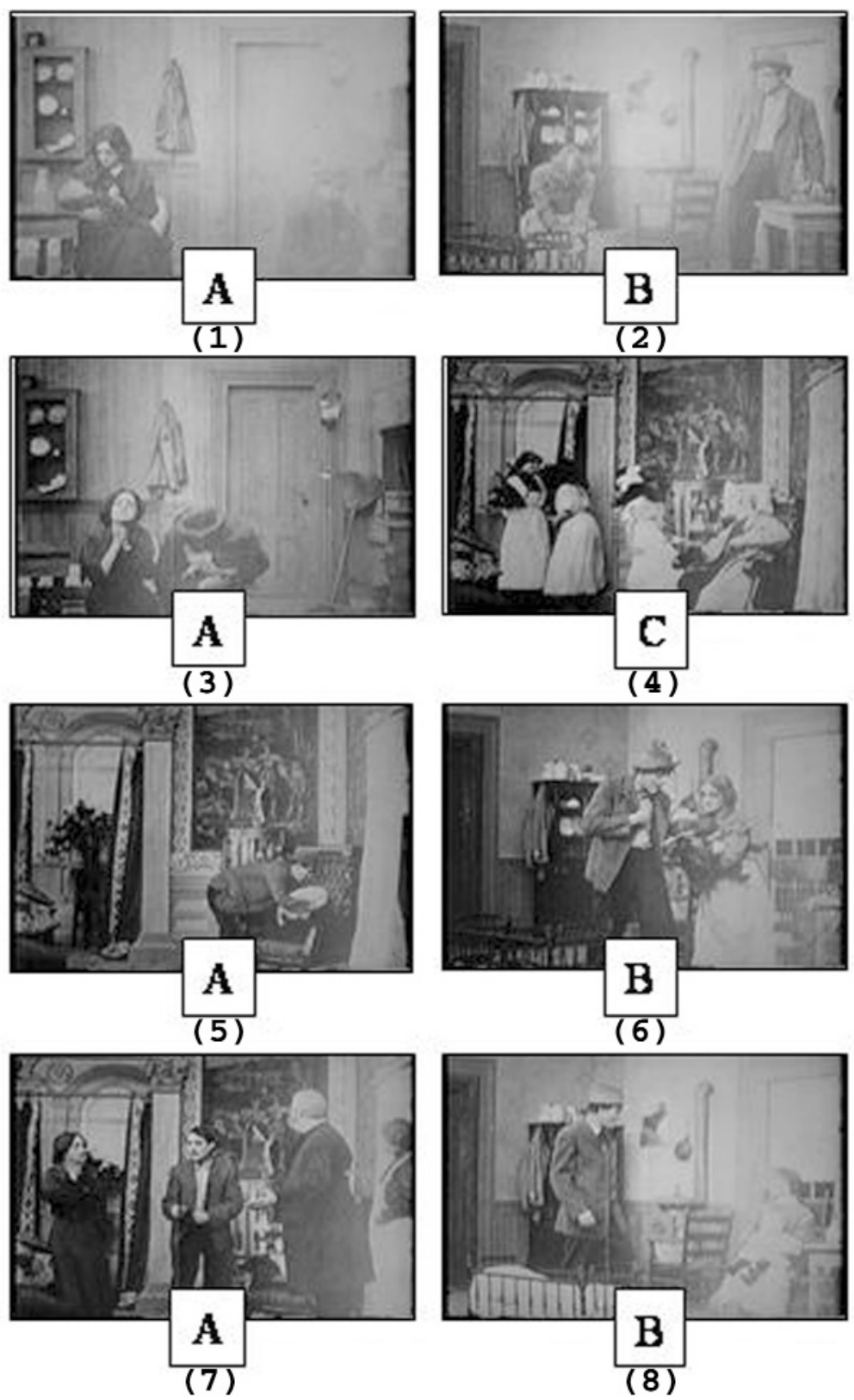

134 CiNeMAS, vol. 15, n"2-3 

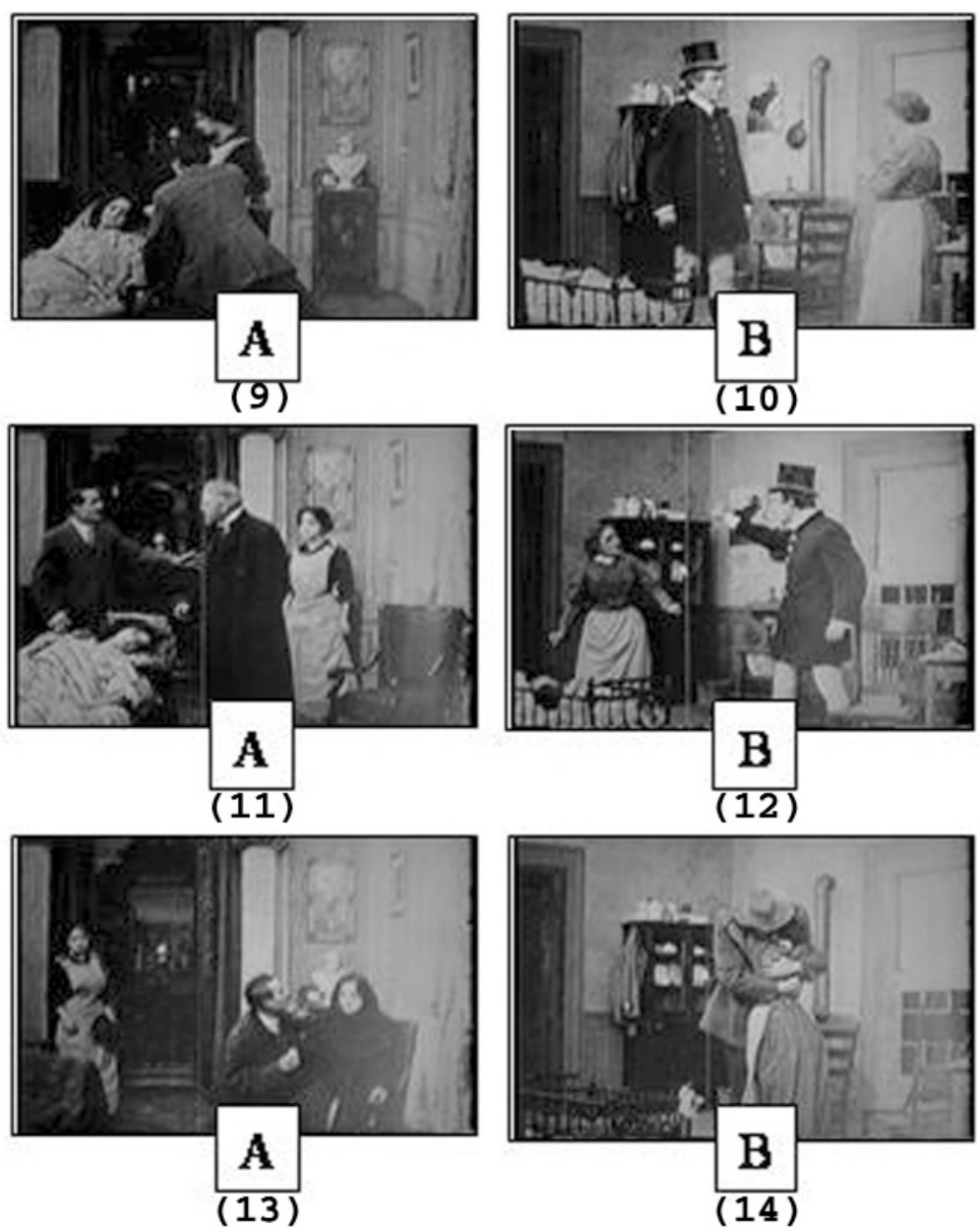

Figure 2. Structure narrative en alternance de His Last Burglary (Biograph, 1910). 
in his hurried exit neglected to close it, so he enters and begins to explore the place. The cooing of the baby startles him, and after reading the note, Standish has left, an idea strikes him. Why not take the baby. Truly, it is a new kind of loot, but it may mean happiness for his wife. This thought decides him, so he rushes to his home with the child. The bereft wife is raised to the very zenith of joy at its appearance, and the burglar himself becomes regenerated, declaring he is through with his past life and will now live worthy of the blessing God has bestowed. To this end he goes to seek honest employment.

Vient ensuite la deuxième (et dernière) occurrence de l'ensemble actantiel A:

Meanwhile, there has been a change in the conditions of the parents of the baby. On their return home they find a letter accepting the invention upon a $\$ 5,000$ yearly royalty, enclosing a check in payment of the first quarter. Thus has fortune smiled and they hurry back to reclaim their child. Of course, the minister doesn't know anything about it. The whole affair is plunged into absolute mystery, and the poor mother, when taken to the comfortable home their new fortune provides, is seriously ill from her mine-wrecking grief.

Puis, finalement, le tout se termine avec la deuxième (et dernière) occurrence de l'ensemble actantiel B :

Now, it happens that the burglar has become the coachman of the doctor who is attending her, and so he learns the identity of the foundling. His heart touched by the suffering of the poor woman, he hastens home, dons his burglar attire, steals into the woman's room, and lays the baby beside her while she sleeps. This act not only restores the suffering woman, but it has softened his hitherto hard and indifferent heart, making for all time, a real man of him.

Que constate-t-on, une fois cette comparaison effectuée? On constate d'abord que, même si les deux textes, le scriptural et le filmique, sont fondés sur le mode de l'alternance entre deux foyers (d'une part, la tranche de vie du cambrioleur et, de l'autre, celle de l'inventeur), le rythme et les modalités de 


\section{RELEASED February 21, 1910 HIS LAST BURGLARY}

HOW A BABY'S PRESENCE REGENERATES HIM

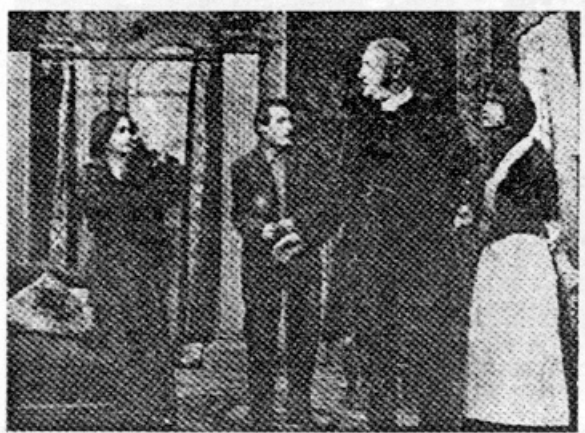

The Scottish poet, Robert Pollock, called children "Living jewels drupp_d unstained from heaven", and this esteem is backed by Scriptural evidence, for the Saviour came to us as a child. He ever specialized the child. He taught that a little child should lead them. And so it is; the tiny hand of the baby has ever been the propelling force of the universe. Never was this more vividly portrayed than in this Bingraph subject. William Standish, a young inventor, like many of his ilk, has spent time, money and energy in perfecting a machine which the engineers to whom he had submitted it are slow in deciding upon, during which time he and his little family of $\because$ wife and infant child are in poverty's clutches. Starvation stares them in the face The baby gives them the most concern, and after a desperate mental struggle, they decide to leave it clandestinely in the minister's care. To this end they go to the minister's house at night, and heing the dead of winter haven't the heart to leave it on the stoop, so Standish climbs through the window and leaves it in the sitting-room s:n an arm-chair. In the neighborhood there lives a professional burglar, whose wife we see bondling over an empty cradle mourning the loss of her child. The burglar, lespite his calling, is moved by his wife's sorrow, and leaves the house dejectedly on an expedition. The open window in the mmister's home looks rather inviting, Standish in his hurried exit neglected to close it, so he enters and hegins to explore the place. The cooing of the baby startles him, and after reading the note, Standish tact left, an idea strikes him. Why not take the baby. Truly, it is a new kind of loot, but it may mean happiness for his wife. This thought decides him, so he rushes to his home with the child. The bereft wife is raised to the very zenith of joy at its appearance, and the burglar himself becomes regenerated, declaring he is through with his past life and will now live worthy of the blessing God has bestowed. To this end he goes to seek honest employment. Meanwhile, there has been a change in the contitions of the parents of the baby. On their return home they find a letter accepting the invention upon a $\$ 5,000$ yearly royalty, enclosing a check in payment of the first quarter. Thus has fortune smiled and they hurry back to reclaim their child. Of course, the minister doesn't know anything abett it. The whole affair is plunged into alsolute mystery, and the poor mother, when taken to the comfortable home their new fortune provides, is seriously ill from her mine-wrecking grief. Now, it happens that the burglar has become the coachman of the doctor who is attending her. and so learns the identity of the foundling. His heart touched by the suffering of the poor woman, he hastens home, dons his burglar attire, steals into the woman's rom, and lays the baby beside her while she sleeps. This act not only restores the suffering woman, but it has softened his hitherto hard and indifferent heart. makino for ali time, a real man of hils.

APPROXIMATE LENGTH 995 FEET. No. 3670 CODE WORD-REZUMARSE

\section{Produced and Controlled Exclusively by BIOGRAPH COMPANY II East 14th Street, New York City. GEORGE KLEINE SELLING AGENT FOR CHICAGO 52 STATE STREET. CHICAG0, ILL.}

Figure 3. Biograph Bulletin, n 3670, 21 février 1910.

Du filmique au littéraire: les textes des catalogues de la cinématographie-attraction 
l'alternance sont tout à fait différents. On remarque, en effet, que les structures de découpage divergent de façon importante: alors que le méga-narrateur filmique présente la ligne d'action $\mathrm{A}$ et la ligne d'action $B$ selon une alternance systématique, passant avec facilité de l'univers de l'inventeur à celui du cambrioleur, le narrateur scriptural choisit, lui, de regrouper et de concentrer les actions et les événements fictionnels en fonction de leur appartenance à la tranche de vie du couple $\mathrm{A}$ ou du couple $\mathrm{B}$, réduisant l'alternance à son minimum.

On peut avancer l'interprétation suivante. Le récit scriptural semble assez peu disposé à rendre compte, par une narration verbale, de la succession rapide propre au montage cinématographique. Il favorise plutôt le regroupement des actions selon leur série d'appartenance, selon la cohérence des tranches de vie réunies en fonction des personnages et de leur espace domestique propre. Le récit scriptural montre donc les deux sphères diégétiques comme des sphères relativement insécables. La fabula est pourtant commune aux deux récits, le scriptural et le filmique. La structure narrative de His Last Burglary correspond d'ailleurs à peu près parfaitement à celle d'un carré sémiotique idéal (Greimas lui-même n’aurait pu rêver mieux!). En effet, le récit est déclenché par l'opposition structurale initiale entre un excédent, d'une part, et un vide, de l'autre: au bébé présent, mais dont on doit se défaire (douloureusement), par nécessité matérielle, répond le bébé absent, perdu, et que l'on rêve de retrouver. La suite du scénario n'est que la conséquence de cette tension initiale. Mais, à côté de cette ressemblance en termes de fabula, il existe une différence assez radicale en termes de narration et de stratégie narrative.

Sur le plan de la narration, en effet, tout se passe comme si le texte scriptural ne pouvait gérer que difficilement la systématicité du montage cinématographique et la rapidité de l'alternance. Dans sa manière de produire de l'alternance visuelle, le montage du film manifeste une forme de "cinégénie » - ou de médiagénie, selon le concept déjà proposé par l'un des auteurs du présent texte ${ }^{8}$ - dont l'une des caractéristiques est cette façon qu'il a de montrer sa facilité à passer d'une sphère à l'autre, voire de célébrer les performances dont sont capables 
une caméra mobile et un dispositif filmique, qui arrivent à passer sans difficulté d'un univers diégétique à l'autre. On pourrait même se demander s'il n'y aurait pas, chez Griffith, une certaine complaisance, d'ordre "cinégénique», dans cette pratique enthousiaste de l'alternance et du montage...

Cette interprétation "positive», et faisant la part belle à la cinégénie, n'est cependant pas la seule interprétation possible. Il en existe une autre, plus fonctionnelle et plus prosaïque. Elle découle en quelque sorte de l' «encombrement" réaliste qu'entraîne la captation-restitution de l'espace-temps, à laquelle se prête le dispositif cinématographique. L'alternance permet d'éviter à bon compte les incohérences que pourrait produire, à l'écran, une simple consécution de scènes. Difficile, par exemple, de présenter dans une continuité de plans (qui pourraient laisser supposer une simple continuité temporelle sans ellipse) les transformations vestimentaires des protagonistes, qui vont et viennent, en circulant de-ci, de-là, par-ci, par-là dans l'univers diégétique, au gré du scénario. Ainsi est-il plus commode pour le méga-narrateur filmique, au moment où le cambrioleur décide de se dépouiller de ses vêtements afin de rompre avec son ancienne vie, de passer à autre chose pendant le temps nécessaire au cambrioleur pour qu'il se change, et de montrer ce qui se passe, pendant ce temps, dans l'autre série événementielle, celle de l'inventeur. Autrement dit, le manque de vraisemblance que pourrait comporter le changement trop rapide des vêtements est contrebalancé, compensé, par la capacité du montage à suspendre provisoirement un espace-temps, suspension qui indique au spectateur que, entre un aller et un retour, du temps s'est passé, diégétiquement. L'alternance permet donc de préserver ou de construire? - la crédibilité du temps diégétique.

Bref, l'utilisation cinégénique du potentiel du média d'un côté et, de l'autre, la préservation du vraisemblable (du vraisemblable dans un contexte cinématographique) permettent de montrer la performance spécifique du média, tout en servant les intérêts, en termes de vraisemblance, de la narration cinématographique.

Pour en revenir à la problématique qui nous occupe, ce qui précède permet de donner un cadre explicatif pour rendre 
compte de cette différence entre un texte visuel cinégénique et le texte à velléité «littéraire ( "littérogénique» ?) du descriptif. Le publirédacteur de celui-ci semble avoir pris conscience du fossé qui s'est creusé entre les deux médias. Le récit du catalogue est préférablement construit selon la cohérence de chacune des sphères d'actions-personnages, unifiées selon les règles romanesques classiques. Le catalogueur ne cherche pas à relayer par les mots la facilité qu'a le cinéma à faire voyager la caméra d'un lieu à l'autre. Autres temps, autres mœurs...

On peut supposer qu'à une autre époque, celle des catalogues de la cinématographie-attraction que nous avons décrits tout à l'heure, le scriptural aurait suivi au plus près la rapide alternance ou, du moins, en aurait rendu compte, malgré l'obstacle de la frontière médiatico-sémiotique.

Notre comparaison pourrait se prolonger par l'observation des faits et informations concernant la diégèse, qui sont présents dans l'un des médias et absents dans l'autre. Existe-t-il une explication compatible avec ce que nous venons d'exposer pour rendre compte de ce que le texte scriptural ajoute et de ce qu'il néglige par rapport à l'énoncé — et à l'énonciation — filmique? Autrement dit, les ajouts d'information et/ou les ellipses entraînant le retranchement de certaines informations peuventils être associés à nos considérations relatives à la cinégénie (et à la littérogénie) et au vraisemblable médiatique?

Allons-y d'un constat prévisible, tout d'abord. On voit se confirmer, dans His Last Burglary, la difficulté de montrer, à l'aide des images — et de leur précision analogique — des entités abstraites et morales, telle la pauvreté. Pour évoquer "iconiquement» cette dernière, on ne peut montrer que des "choses pauvres» ou des gens pauvres. Les contraintes de la monstration exigent que l'on propose à la vue des morceaux de réel en rapport métonymique ou métaphorique avec la pauvreté, des incarnations visuelles de la pauvreté. Preuve de cette difficulté, le monstrateur ressent le besoin d'exhiber le mot "POVERTY» pour ancrer l'interprétation des images (figure 4).

Par ailleurs, le texte scriptural se différencie aussi du texte iconique par l'ajout de précisions et d'informations circons- 


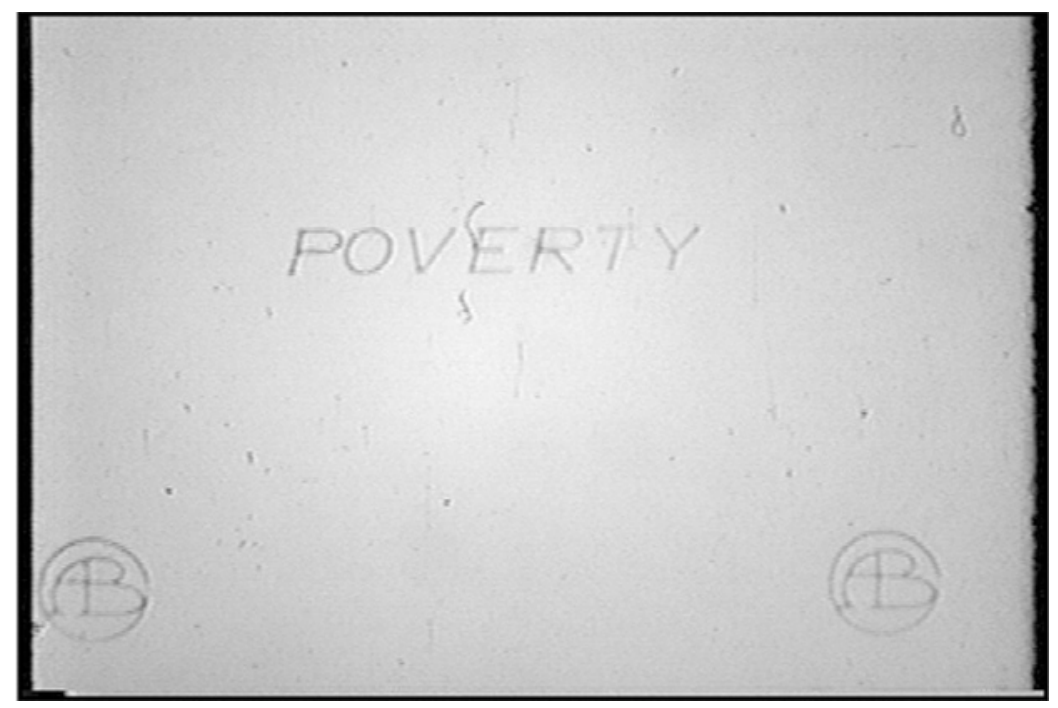

Figure 4. Intertitre dans His Last Burglary (Biograph, 1910).

tancielles. Il y est ainsi précisé que l'inventeur a soumis son projet à des ingénieurs et qu'il attend une réponse de leur part. On apprend aussi que l'action se passe à la fin de l'hiver et que les parents n'ont donc pas le cœur à abandonner leur enfant sur le perron de la demeure du pasteur. Cette information remplit au moins une double fonction. D'une part, elle confere implicitement à la scène de pauvreté "écrite " une "plus-value ", sur le plan de la dramatisation, que le texte filmique ne possède pas comme telle; d'autre part, elle donne une motivation, une consistance psychologique (une motivation rationnelle) aux actes posés par le personnage - on comprend pourquoi l'inventeur décide d'entrer chez le pasteur: c'est pour que l'enfant qu'il abandonne s'y trouve à l'abri des rigueurs de cette fin d'hiver.

Dans le texte du descriptif, tout s'enchaîne d'ailleurs selon une consécution typiquement littéraire: comme l'inventeur est rentré par là, le voleur pourra à son tour s'y introduire. Le descriptif scriptural n'hésite donc pas à nourrir les faisceaux de causalité narrative et à rendre plus consistante la motivation psychologique des personnages. C'est ce qui se produit dans le passage suivant (voir notamment la phrase que nous soulignons): "Why not take the baby. Truly, it is a new kind of loot, 
but it may mean happiness for his wife. This thought decides him, so he rushes to his home with the child."

Cette précision construit - ou à tout le moins renforce l'image (et aussi le cliché littéraire) du délinquant au grand cœur qui, au-delà des actes répréhensibles qu'il commet, songe tout de même au bonheur de sa conjointe, toutes choses qui n'apparaissent pas dans le film, en tout cas pas de façon explicite. Le descriptif agit donc comme un vecteur de renforcement du principe de motivation et de causalité narratives. Le texte scriptural cherche en quelque sorte à motiver les actes posés par les personnages; pas le texte filmique. Peut-être est-il alors possible de parler de vraisemblable comparé, le vraisemblable du film à l'époque de His Last Burglary n'étant pas de même nature que celui du récit littéraire.

Notons encore que le surplus relatif d'information peut aussi, dans certains cas, pencher du côté du film. L'exemple le plus probant à cet égard intervient au moment où l'on présente au spectateur la maison du pasteur, avant que l'inventeur ne vienne y déposer son enfant. La monstration de l'espace domestique de cette demeure se trouve animée par une sorte de chorégraphie spontanée offerte par les filles du pasteur (figure 5). On ne trouve aucune trace de cette brève scène de danse dans le récit scriptural. Cette différence pourrait aussi s'expliquer, nous semble-t-il, par des facteurs relevant de la cinégénie. La danse des jeunes filles ne constitue en rien une fonction cardinale du récit, pour reprendre la terminologie de Roland Barthes. Elle est narrativement anecdotique et ne contribue même pas directement à assurer la vraisemblance du récit. Ce qu'apporte la scène relève, d'une part, de la connotation culturelle: la danse des jeunes filles signifie implicitement un foyer aisé où il fait bon vivre, à mille lieues des tracas matériels qui sont le lot de l'inventeur et de sa famille. D'autre part, et voici la dimension cinégénique de la séquence, cette animation chorégraphique introduit de la dynamique et de la rythmicité dans le profilmique. Durant ce court instant, la monstration prend une allure plus attractive, pour ne pas dire «attractionnelle». La description de personnages dansants n'ayant pas les mêmes qualités du côté du scriptural, le publirédacteur ne ressent pas même le besoin d'y faire allusion dans son texte. 


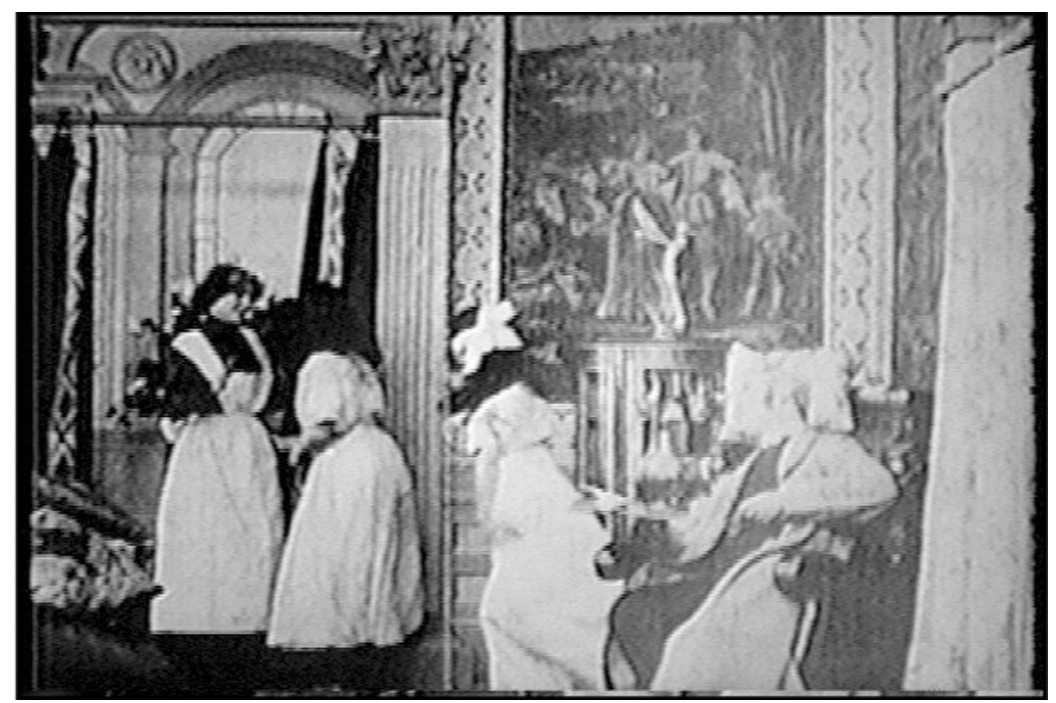

Figure 5. Photogramme tiré de His Last Burglary (Biograph, 1910).

\section{Conclusion}

Pour nous aider à conclure brièvement sur ce type particulier de novellisation - de protonovellisation - que représentent les descriptifs des catalogues, il nous faut apporter une précision importante à notre commentaire de His Last Burglary. Il se peut en effet (point de certitude à cet égard) que le texte du Biograph Bulletin ait des origines préfilmiques (et qu'il ne soit pas simplement postfilmique). Ce texte a en effet pu être rédigé à partir d'un scénario non encore filmé. Si tel est le cas, et que de l'écrit (le scénario) on ait abouti à de l'écrit (le bulletin), on ne peut plus parler de novellisation! Il se peut même, autre hypothèse, que la rédaction du bulletin soit effectivement postérieure au film dont elle doit rendre compte, mais que le scénario initial ait servi de base à sa rédaction, et ce malgré l'existence du film. Ce qui, d'ailleurs, ne serait pas incompatible avec ce que nous avons proposé ici: les publirédacteurs qui s'inscrivent dans le paradigme de l'intégration narrative ont depuis longtemps renoncé au mimétisme des catalogueurs de la cinématographie-attraction. Dorénavant, on ne cherche plus à relayer scripturalement, dans une sorte d'enthousiasme indiciel, l'effet novelty qui se dégage du nouveau média. Il se peut alors que cette prise de distance relative, face à la nature du média, au 
profit de la fabula qu'il propose - ce que nous avons défini comme une sorte de retour au littéraire - , il se peut donc que cette façon de concevoir les descriptifs ait poussé le rédacteur à faire davantage confiance au scénario écrit qu'au flux d'images animées que constitue le film.

Il reste que, en plein cœur de la poussée institutionnalisante du tournant des années 1910, la tendance dominante mène directement à la production de textes distincts: d'un côté, un texte filmique, spécifique et autonome; de l'autre, un texte scriptural qui, pour rendre compte du premier, reste à cent lieues du mimétisme descriptif des premiers catalogueurs. La préoccupation dominante s'est transformée: il s'agit non plus de rendre l'idée du film par la traduction, par le truchement du canal linguistique, de son mouvement et de ses variations, mais plutôt d'opérer la transposition de cette idée dans le média scriptural d'arrivée, en respectant celui-ci et ses principes. Une fois l'effet novelty du cinéma estompé, l'écriture "littéraire " peut donc reprendre ses «droits", en laissant intacts ceux de ce nouvel «être» juridique en voie de formation: le cinéma-encours-d'institutionnalisation.

\section{Université de Montréal et Université Catholique de Louvain}

\section{NOTES}

1. Le présent texte a d'abord fait l'objet d'une communication au colloque international Narrating the Film-Novelization: From the Catalogue to the Trailer (Università degli Studi di Udine, Italie, mars 2005). Côté belge, la réflexion et la recherche dont il fait état s'inscrivent dans le cadre des travaux de l'Observatoire du récit médiatique (ORM) de l'Université Catholique de Louvain. Côté québécois, il a été écrit dans le cadre des travaux du GRAFICS (Groupe de recherche sur l'avènement et la formation des institutions cinématographique et scénique) de l'Université de Montréal, subventionné par le Conseil de recherches en sciences humaines du Canada et le Fonds québécois pour la recherche sur la société et la culture. Le GRAFICS fait partie du Centre de recherche sur l'intermédialité (CRI).

2. Voir Gaudreault et Marion 2004 (actes du colloque international Poétique de la novellisation: médias et adaptation, Université de Louvain, Leuven et Louvainla-Neuve, novembre 2003).

3. Voir Gaudreault 2004 (cet ouvrage paraittra en français aux Éditions du CNRS en 2006).

4. Catalogue Williamson (septembre 1902), film intitulé Two Naughty Boys Teasing the Cobbler.

5. Voir Gaudreault et Gunning 1989. 
6. Catalogue Williamson (septembre 1902), film intitulé Two Naughty Boys Upsetting the "Spoons".

7. Catalogue Edison (février 1903). C'est nous qui soulignons.

8. Voir Marion 1997.

\section{RÉFÉRENCES BIBLIOGRAPHIQUES}

Bowser 1973 : Eileen Bowser, Biograph Bulletins 1908-1912, New York, Ferrar, Straus \& Giroux, 1973.

Coissac 1911 : G.-Michel Coissac, "La conférence cinématographique», CinéJournal, $\mathrm{n}^{\circ} 161,1911$, p. 41-48.

Gaudreault 2004: André Gaudreault, Cinema delle origini. O della "cinematografiaattrazione», Milano, Il Castoro, 2004.

Gaudreault et Gunning 1989: André Gaudreault et Tom Gunning, "Le cinéma des premiers temps: un défi à l'histoire du cinéma?", dans Jacques Aumont, André Gaudreault et Michel Marie (dir.), Histoire du cinéma. Nouvelles approches, Paris, Publications de la Sorbonne, 1989, p. 49-63.

Gaudreault et Marion 2004: André Gaudreault et Philippe Marion, «Les catalogues des premiers fabricants de vues animées: une première forme de novellisation?», dans Jan Baetens et Marc Lits (dir.), La novellisation. Du film au livre/Novelization: From Film to Novel, Leuven, Leuven University Press, 2004, p. 41-59.

Marion 1997 : Philippe Marion, "Narratologie médiatique et médiagénie des récits", Recherches en communication, $\mathrm{n}^{\circ}$ 7, 1997, p. 61-87. 